\title{
Latitudinal patterns and interannual variations of spring phytoplankton in relation to hydrographic conditions of the southwestern Atlantic Ocean $\left(34^{\circ}-62^{\circ} \mathrm{S}\right)$
}

\author{
Héctor F. Olguín Salinas • Frederico Brandini • \\ Demetrio Boltovskoy
}

Received: 21 July 2014/Revised: 29 January 2015/Accepted: 3 February 2015/Published online: 15 February 2015

(C) Springer-Verlag Berlin Heidelberg and AWI 2015

\begin{abstract}
In the present study, the distribution and abundance of microphytoplankton were assessed in the southwestern Atlantic Ocean from subtropical to polar waters $\left(34^{\circ}-62^{\circ} \mathrm{S}\right)$ in two austral springs with contrasting hydrographic conditions. Vertical profiles of open-ocean (ca. $54^{\circ} \mathrm{W}$ ) samples ( $\geq 18 \mathrm{~L}$ filtered water) were performed in 20 stations $(0-100 \mathrm{~m})$ in 1994 and in 17 stations $(0-50 \mathrm{~m})$ in 1995. The latitudinal patterns of microphytoplankton groups, chlorophyll $a$, and diatom and silicoflagellate species were analyzed and compared with our previous study carried out in spring $1993\left(30^{\circ}-61^{\circ} \mathrm{S}\right)$. In the three springs, 197 diatom species, 173 of which showed mean relative density lower than $1 \%$, were identified. A consistent diatom biogeographic pattern emerged in the three consecutive springs, defining the Transitional (corresponding to the Brazil-Malvinas Current Confluence), Subantarctic and Antarctic Zones; and the Subantarctic and Polar Fronts, as
\end{abstract}

Communicated by H.-D. Franke.

H. F. Olguín Salinas · D. Boltovskoy

Departamento de Ecología, Genética y Evolución, Instituto

IEGEBA (CONICET-UBA), Facultad de Ciencias Exactas y

Naturales, Universidad de Buenos Aires, Pabellón II,

C1428EHA Buenos Aires, Argentina

H. F. Olguín Salinas $(\bowtie) \cdot D$. Boltovskoy

Museo Argentino de Ciencias Naturales, A. Gallardo 470,

C1405DJR Buenos Aires, Argentina

e-mail: holguin@ege.fcen.uba.ar

F. Brandini

Instituto Oceanográfico da Universidade de São Paulo, Praça do

Oceanográfico, 191, São Paulo, SP 05508-120, Brazil

D. Boltovskoy

Consejo Nacional de Investigaciones Científicas y Técnicas,

Av. Rivadavia 1917, C1033AAJ Buenos Aires, Argentina their boundaries. This zonation reflects persistent features of this hydrographically heterogeneous region. The Polar Front was a weaker biogeographic boundary for diatom species than the Subantarctic Front. Interannual changes in diatoms (mainly in species richness, dominant species and degree of dominance of species with different ecological affinities) were detected. The Transitional Zone, which is one of the most hydrographically variable regions of the world ocean, showed the highest changes in the diatom assemblage, reflecting a colder spring in 1995 and a warmer spring in 1994 than normal (1993). These changes agreed with differences reported for 1993-1995 in large-scale hydrographic conditions, including a widespread diversity decrease in 1995 due to a weaker influence of subtropical waters.

Keywords Diatoms · Biogeography · Atlantic · Brazil-Malvinas Confluence

\section{Introduction}

Strong persistent currents along the western boundaries of the world's major ocean basins are some of the most prominent features of ocean circulation (Imawaki et al. 2013).

The southwestern Atlantic Ocean (SWA) encompasses portions of the eastern shelf of South America and the deep ocean of one of the most energetic and biologically productive oceanic regions of the southern hemisphere (Combes and Matano 2014a). The SWA is characterized by two of the largest western boundary currents of the world ocean that flow in opposite directions: the cool nutrientrich Malvinas (=Falklands) Current, which transports subantarctic waters toward the north along the eastern side of 
the Argentine Shelf break, and the warm saline oligotrophic Brazil Current, which flows south along the narrow Brazilian Shelf (Matano et al. 2010) (Fig. 1). Between ca. $30^{\circ}$ and $46^{\circ} \mathrm{S}$, these two currents come in contact with each other, defining the Brazil-Malvinas Confluence Zone (BMCZ), a permanent feature characterized by the interleaving and mixture of subantarctic and subtropical waters, as well as strong mesoscale features, such as thermohaline fronts, rings, filaments and eddies (Olson et al. 1988; Peterson and Stramma 1991; Peterson 1992; Willson and Rees 2000). This zone of complex hydrodynamics and rich spatial structure (d'Ovidio et al. 2010) is identified as a hot spot of enhanced phytoplankton diversity (Follows et al. 2007).

Adjacent to the BMCZ is the Argentine Shelf, one of the world's largest continental shelves. Both zones are of great importance due to their ecological and biogeochemical features (Schloss et al. 2007; d'Ovidio et al. 2010) and recognized among the richest chlorophyll $a$ areas, according to ocean color satellite images (Saraceno et al. 2005; Rivas et al. 2006).

At latitudes higher than $\sim 45^{\circ} \mathrm{S}$, the Antarctic Circumpolar Current (ACC) flows constantly from west to east connecting three large ocean basins (Pacific, Atlantic and

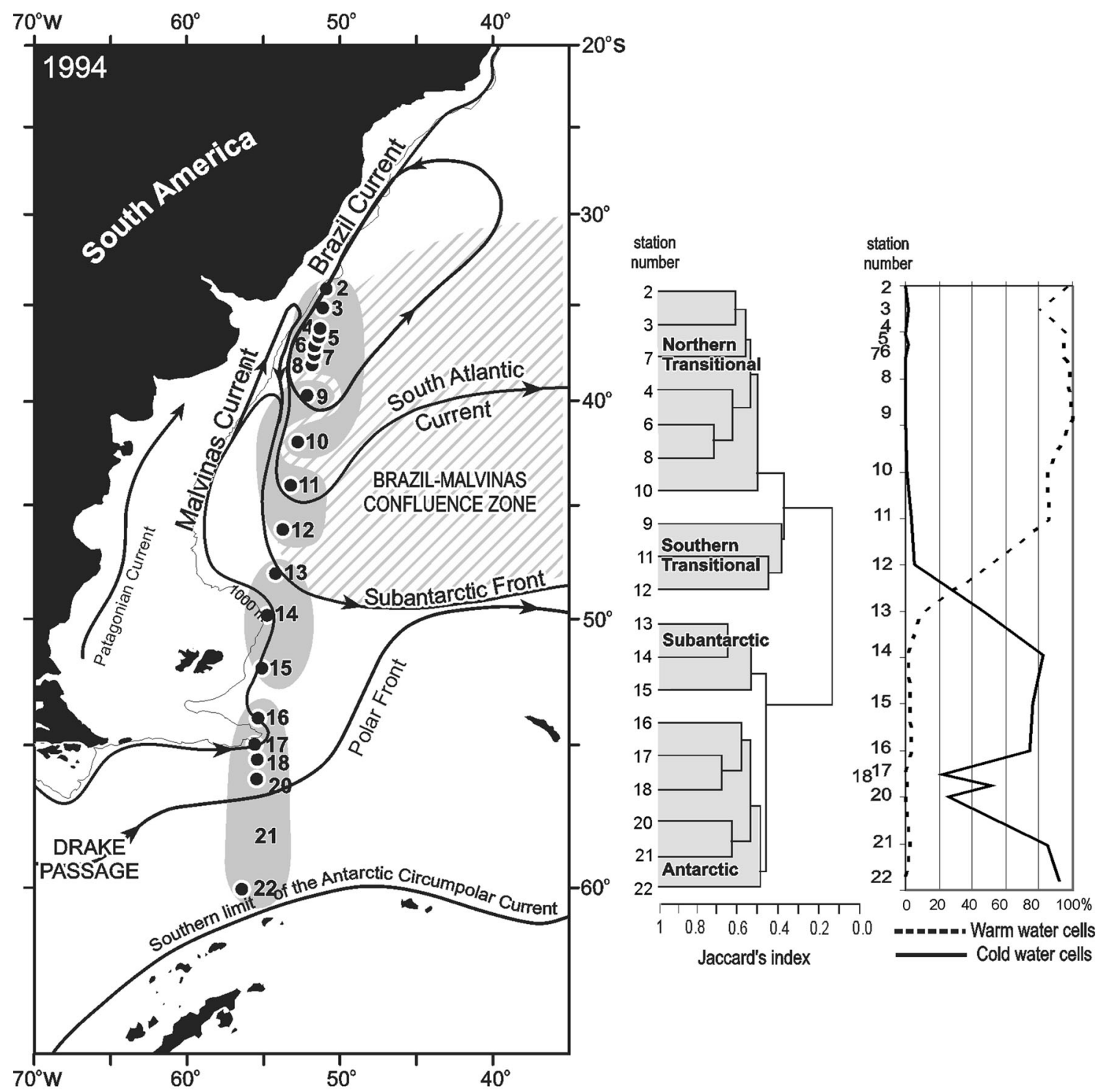

Fig. 1 General surface circulation pattern in the southwestern Atlantic Ocean modified from Peterson and Stramma (1991). Location of sampling stations and biogeographic zonation resulting from the cluster analyses (UPGMA) based on the diatom (Jaccard's index) depth-integrated data for the sites surveyed in November 1994 (cluster illustrated in the adjacent graph). Curves on the right-hand side of the graph show proportions of warm-water and cold-water individuals at the latitude of each sampling station (marked by their number) 
Indian Oceans) (Orsi et al. 1995). The cold and nutrientrich water masses of the ACC are characterized by strong iron limitation, influencing the distribution of marine diatom species, in contrast to their northern hemispheric counterparts, where phytoplankton growth is primarily limited by nitrate (Cermeño and Falkowski 2009).

The SWA circulation patterns and seawater surface temperature show temporal variations from subseasonal to seasonal and interannual scales (Olson et al. 1988; Witter and Gordon 1999). These variations are strongly influenced by interactions between the opposing flows of the Brazil and the Malvinas Currents, which in turn are affected by the basin-scale wind field and other atmospheric features, such as the South Atlantic Convergence Zone (Campos et al. 1999).

The spatial structure of plankton communities in the SWA is mainly controlled by the circulation of the Brazil and the Malvinas Currents, by the large confluence zone between these two currents, and by the permanent and semipermanent fronts (Peterson 1992; Boltovskoy 1999; Thompson et al. 1999; Boltovskoy et al. 2000; Thompson et al. 2001; Olguín et al. 2006; Gonçalves-Araujo et al. 2012).

Diatoms are a key component of oceanic systems, responsible for a great part of the marine primary production (Werner 1977; Armbrust 2009) and for over half of the total biogenic silica (Romero and Armand 2010). Because diatoms are widespread, very abundant and highly diversified, they are successfully used in biogeographic and paleoceanographic surveys, especially in those focused on monitoring changes in modern oceanographic conditions (Smetacek 1985; Ragueneau et al. 2000; Stoermer and Smol 2001; Romero and Armand 2010). Due to the prominent role of planktonic diatoms in biogeochemical cycles, the interpretation of shifts in their abundance and distribution is relevant for analyses of long-term climate forcing (Bopp et al. 2005), especially in this circulation system characterized by very high interannual variability (Goni and Wainer 2001).

Many studies have considered the distribution of phytoplankton or especially diatoms in the Argentine Shelf (e.g., Sar et al. 2001; 2002; Almandoz et al. 2007; Olguín and Alder 2011; Sabatini et al. 2012), as well as in some sectors of the BMCZ (Lange 1985; Lange and Mostajo 1985; Gayoso and Podestá 1996; Gonçalves-Araujo et al. 2012). These studies have found a high spatial heterogeneity in both the abundance and the assemblage structure of diatoms.

The study of the spatial distribution of microphytoplankton, particularly of diatoms at macroscale, has received less attention in the oceanic region of the SWA to the north of the Polar Front (Barlow et al. 2002) than in the southeast Atlantic Ocean (e.g., Froneman et al. 1995; Eynaud et al. 1999).
More extensive studies in the oceanic region adjacent to the Argentine Shelf (including not only the BMCZ) have examined the structure of phytoplankton assemblages at the level of major groups and/or different pigments, measured in situ (Fernandes and Brandini 1999; Brandini et al. 2000; Marañón et al. 2000; Gibb et al. 2000; Barlow et al. 2002) or through remote sensing (Sullivan et al. 1993; Saraceno et al. 2005; Romero et al. 2006; d'Ovidio et al. 2010).

Some researchers have pointed out that the poor resolution at the species level of the phytoplankton community structure in most oceanic systems is one of the limitations for modeling advance (e.g., Boyd et al. 2010).

Studies focused on biogeographical aspects of diatom assemblages at the species level (Hasle 1976; Olguín et al. 2006; Cermeño et al. 2008, 2010; Chust et al. 2013) are insufficient to reflect the high spatial and temporal variability of this extensive open-ocean region, mainly considering that, in general, they are based on few samples in this region.

We have previously highlighted the high proportion of diatom species with low or very low abundance (Olguín et al. 2006). It has been recently recognized that the species richness in conventional phytoplankton studies is severely underestimated (Rodríguez-Ramos et al. 2014). Therefore, a sampling effort appropriate to characterize the species richness of marine diatoms adequately is required to validate pattern analyses and dataset intercomparisons (Cermeño et al. 2014).

The present study, supported by an appropriate sampling, identification and counting effort, takes advantage of the opportunity to compare microphytoplankton patterns in three consecutive springs with different hydrographic conditions.

On the other hand, abrupt changes are observed in the oceanic circulation of the SWA. Combes and Matano (2014b) found that these changes are driven by a weakening of the northern branch of the ACC, which translates to a weakening of the Malvinas Current transport and a southward BMCZ drift, at a reported rate of $0.62 \%$ decade between 1993 and 2008. With this perspective, detailed studies of diatom assemblages will contribute to the comparison over time of this changing region.

The aims of our study were to assess the patterns of abundance and distribution of microphytoplankton groups along two north-south transects $\left(34^{\circ}-62^{\circ} \mathrm{S}\right.$, ca. $\left.54^{\circ} \mathrm{W}\right)$ in the austral springs (November) of 1994 (diatoms and silicoflagellates) and 1995 (diatoms, silicoflagellates and dinoflagellates), to compare the interannual variation in the biogeographic patterns of diatom species assemblages (including our previous spring data of 1993), and to interpret the shifts in diatom species assemblages with respect to the large-scale hydrographic conditions reported for the area during each survey period. 


\section{Materials and methods}

Microphytoplankton samples were collected along a N-S transect $\left(34^{\circ}-60 / 62^{\circ} \mathrm{S} ; 51^{\circ}-56^{\circ} \mathrm{W}\right)$ in the SWA (Figs. 1, 2) during November 1994 (20 stations) and November 1995 (17 stations), on board the oceanographic vessel "Ary Rongel", within the framework of a joint Brazilian-Argentine research program based on chemical and plankton sampling in the South Atlantic. In 1994, phytoplankton samples were collected by means of vertical tows (200-300 L), with a 30- $\mu \mathrm{m}$-mesh closing net provided with a flowmeter, covering the following depth layers: 5-0, $15-5,30-15,50-30$ and $100-50 \mathrm{~m}$. In 1995, phytoplankton samples were collected (18 L) by casting of Niskin bottles at four depths $(5,10,25$ and $50 \mathrm{~m})$ followed by filtration through a $10-\mu \mathrm{m}$-mesh gauze. Comparative analyses also included data obtained in the spring of 1993 (Olguín et al. 2006), when phytoplankton samples (20 stations) were collected as in 1995. All samples were preserved with $5 \%$ buffered formaldehyde. Diatoms and silicoflagellates were counted and identified to species level under an inverted microscope provided with phase contrast. Permanent slides of oxidized Naprax-mounted materials (Simonsen 1974) were prepared to aid in the species identification.

The species abundance values of each vertical profile were depth-integrated (weighted mean) up to $50 \mathrm{~m}$ for

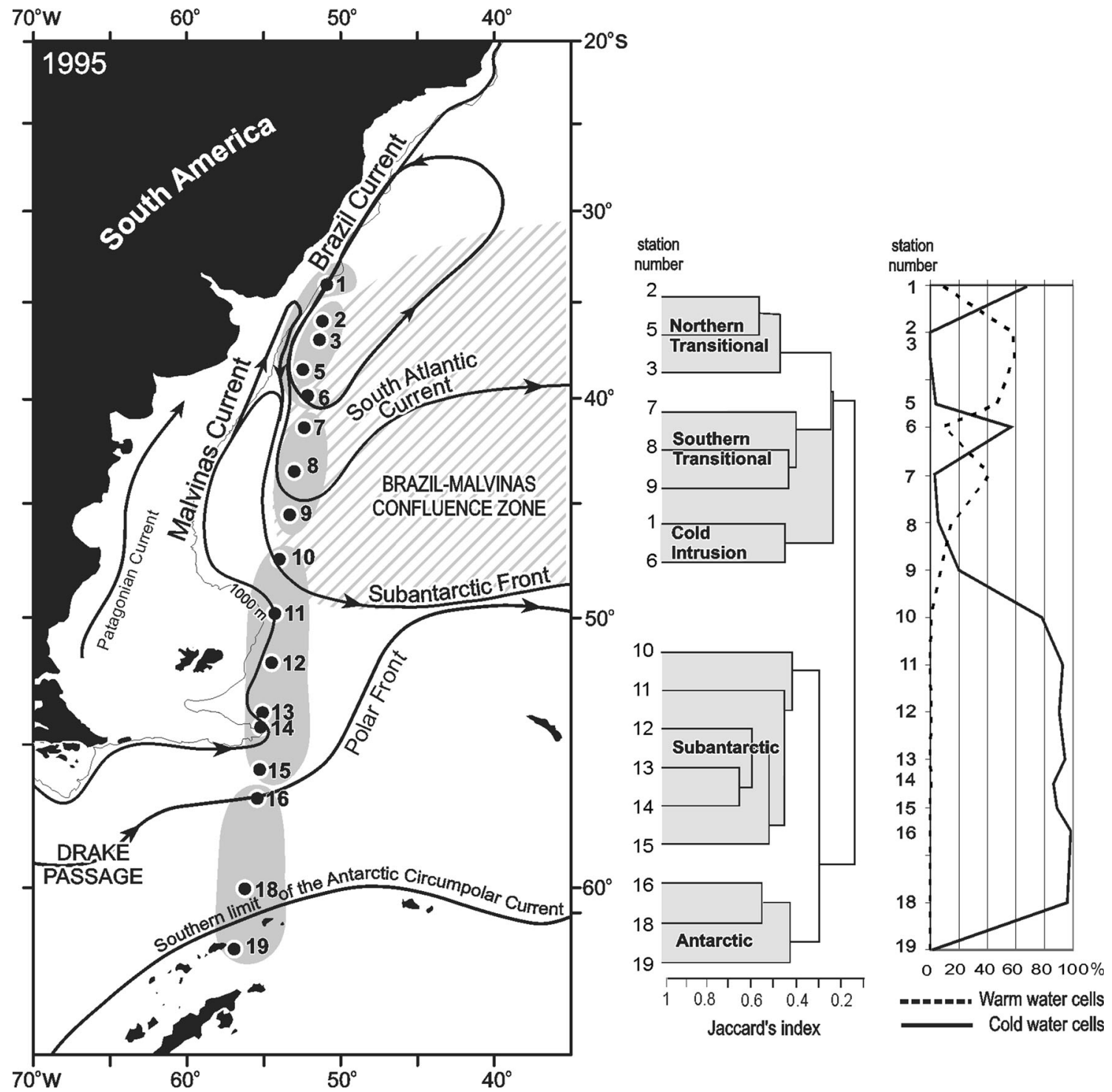

Fig. 2 Location of sampling stations and biogeographic zonation resulting from the cluster analyses (UPGMA) based on the diatom (Jaccard's index) depth-integrated data for the sites surveyed in November 1995 (cluster illustrated in the adjacent graph). Curves on the right-hand side of the graph show proportions of warm-water and cold-water individuals at the latitude of each sampling station (marked by their number) 
interannual comparison purposes. Biogeographic areas were defined using cluster analyses with the UPGMA method based on Jaccard's similarity index.

The difference in the sampling techniques between 1993/1995 (Niskin bottles, $10-\mu \mathrm{m}$ filtration) and 1994 (30- $\mu \mathrm{m}$-net tows) introduced some limitations to the comparison between the distribution patterns in the three spring periods (e.g., cluster analyses based on presence data, rather than on absolute or relative abundances; exclusion of the 1994 dinoflagellate data). Nevertheless, a specific preliminary assessment of the data considered showed no detectable bias in association with these methodological differences. A total of 51 of the 197 diatom species identified had at least one dimension below $30 \mu \mathrm{m}$ and thus may have been undersampled in 1994. However, the number of these species in 1994 was not smaller (41 vs. 49 in 1993 and only 24 in 1995), and their mean relative abundances showed no significant differences (ANOVA; $P=0.12$ ). Also, their occurrence in the different zones, according to their biogeographic patterns, was not associated with mesh size: the species expected to occur in the BMCZ were significantly (ANOVA; $P=0.0002$, Tukey's test) more common during 1993 (present in $44 \%$ of the samples) and 1994 $(39 \%)$ than in $1995(15 \%)$, whereas their presence in the samples south of the subantarctic front was similar for the three surveys (48, 48 and $40 \%$, respectively). Therefore, we argue that the differences in the sampling techniques introduced no detectable bias into the main findings of our study.

\section{Environmental setting}

The Antarctic Circumpolar Current, flowing from west to east around Antarctica, is the dominant circulation feature of the Southern Ocean. Through the Drake Passage (between South America and the Antarctic Peninsula), the ACC is composed of three major jets: the Subantarctic Front (SAF), the Polar Front (PF) and the Southern ACC Front (Combes and Matano 2014a). The Malvinas Current is formed by the northernmost jet (SAF) and, after leaving the Drake Passage, flows northward along the continental slope, until it collides with the poleward flow of the Brazil Current, thus returning to the south as the Malvinas Return Flow (Saraceno et al. 2005). The Brazil Current forms near $15^{\circ} \mathrm{S}$ feeding from the westward flow of the South Equatorial Current. After separating from the coast, it splits into two branches: one retroflecting to the north, where it generates a recirculation cell, and the other flowing farther south. The second path of the Brazil Current is much stronger than the aforementioned redirected path (Combes and Matano 2014a).
During all the three periods surveyed, the SAF (at ca. $\left.48^{\circ}-50^{\circ} \mathrm{S}\right)$ and the $\mathrm{PF}\left(55^{\circ}-57^{\circ} \mathrm{S}\right)$ appeared as the main gradients separating zones with different hydrographic properties (Brandini et al. 2000; Thompson and Alder 2005). North of the SAF, the waters dominated by the BMCZ presented very variable temperatures $\left(7-20^{\circ} \mathrm{C}\right)$ and low nutrient concentrations at the surface $(\leq 4.9 \mu \mathrm{M}$ nitrates; $\leq 0.84 \mu \mathrm{M} \quad$ phosphates; $\leq 2.4 \mu \mathrm{M} \quad$ silicates $)$. Between the SAF and the PF, the colder $\left(\sim 5-7{ }^{\circ} \mathrm{C}\right)$ subantarctic waters showed sharp increases in dissolved nutrients, especially nitrates $(\leq 20 \mu \mathrm{M})$, but also phosphates $(\leq 1.8 \mu \mathrm{M})$ and silicates $(\leq 8 \mu \mathrm{M})$. South of the PF, the waters presented temperatures below $0{ }^{\circ} \mathrm{C}$ and highly increased silicate values $(\sim 11 \mu \mathrm{M})$ (Brandini et al. 2000).

\section{Results and discussion}

Distribution of microphytoplankton abundance and chlorophyll concentration

In 1994 (Fig. 3), diatom abundance varied widely (1-164,000 cells $\mathrm{L}^{-1}$ ), with highest values at some stations of the BMCZ (station $8, \sim 38^{\circ} \mathrm{S}, 5-15 \mathrm{~m}$ ) and around the $\mathrm{PF}$ (station $20, \sim 57^{\circ} \mathrm{S}, 0-5 \mathrm{~m}$ ), and showed no correlation with chlorophyll $a$ concentration $(r=0.05)$. Silicoflagellates were generally scarce $\left(<1,100\right.$ cells $\left.\mathrm{L}^{-1}\right)$, showing higher values in the vicinity of the PF (stations 17 and 18).

In 1995 (Fig. 4), the maximum diatom abundance $\left(<14,000\right.$ cells $\mathrm{L}^{-1}$ ), observed in the BMCZ (station 6, $\sim 40^{\circ} \mathrm{S}$, Fig. 2), was lower than in 1994 , whereas maximum silicoflagellate abundance, observed around the $\mathrm{PF}$ (station 16 , $\sim 57^{\circ} \mathrm{S}$, Fig. 2$)$, was higher $\left(<3,000\right.$ cells $\left.\mathrm{L}^{-1}\right)$. Dinoflagellate abundance was particularly high $(36,000$ cells $\mathrm{L}^{-1}$ in the $\mathrm{BMCZ}$, station $8, \sim 44^{\circ} \mathrm{S}$ ) and significantly correlated in space with chlorophyll $a$ concentration $(r=0.64 ; P<0.05)$ in 1995 (Fig. 4). Likewise, their abundance was very high $\left(<24,000\right.$ cells $\left.\mathrm{L}^{-1}\right)$ and correlated in space with chlorophyll $a(r=0.78 ; P<0.05)$ in 1993 (Olguín et al. 2006).

The highest concentrations of planktonic diatoms assessed in this study were generally lower than those previously reported for austral oceanic waters in spring/summer in the SWA: e.g., $6 \times 10^{5}$ cell $\mathrm{L}^{-1}$ for the BMCZ in September (Gayoso and Podestá 1996) and $3.6 \times 10^{6}$ cell $\mathrm{L}^{-1}$ for subantarctic waters $(\sim$ shelf break front) in November (Fernandes and Brandini 1999), as well as in the southeast Atlantic Ocean: $4.63 \times 10^{5}$ cell $\mathrm{L}^{-1}$ south of the PF in February (Eynaud et al. 1999).

Chlorophyll $a$ (Figs. 3, 4) showed peaks of concentration in some sectors of the BMCZ (station $9, \sim 40^{\circ} \mathrm{S}, 25 \mathrm{~m}$ in 1994; station 7, $\sim 42^{\circ} \mathrm{S}, 10 \mathrm{~m}$ in 1995) and south of the $\mathrm{PF}$ (station $22, \sim 60^{\circ} \mathrm{S}, 50 \mathrm{~m}$ in 1994 ; station $19, \sim 62^{\circ} \mathrm{S}$, 


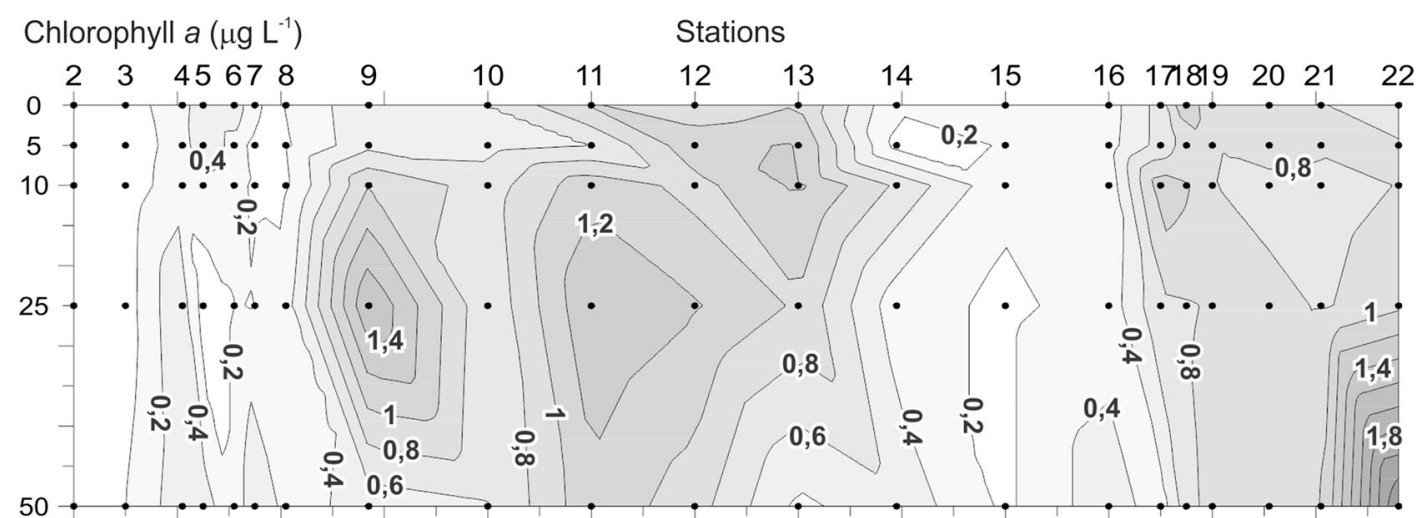

Diatoms (cells $\mathrm{L}^{-1} \times 1000$ )
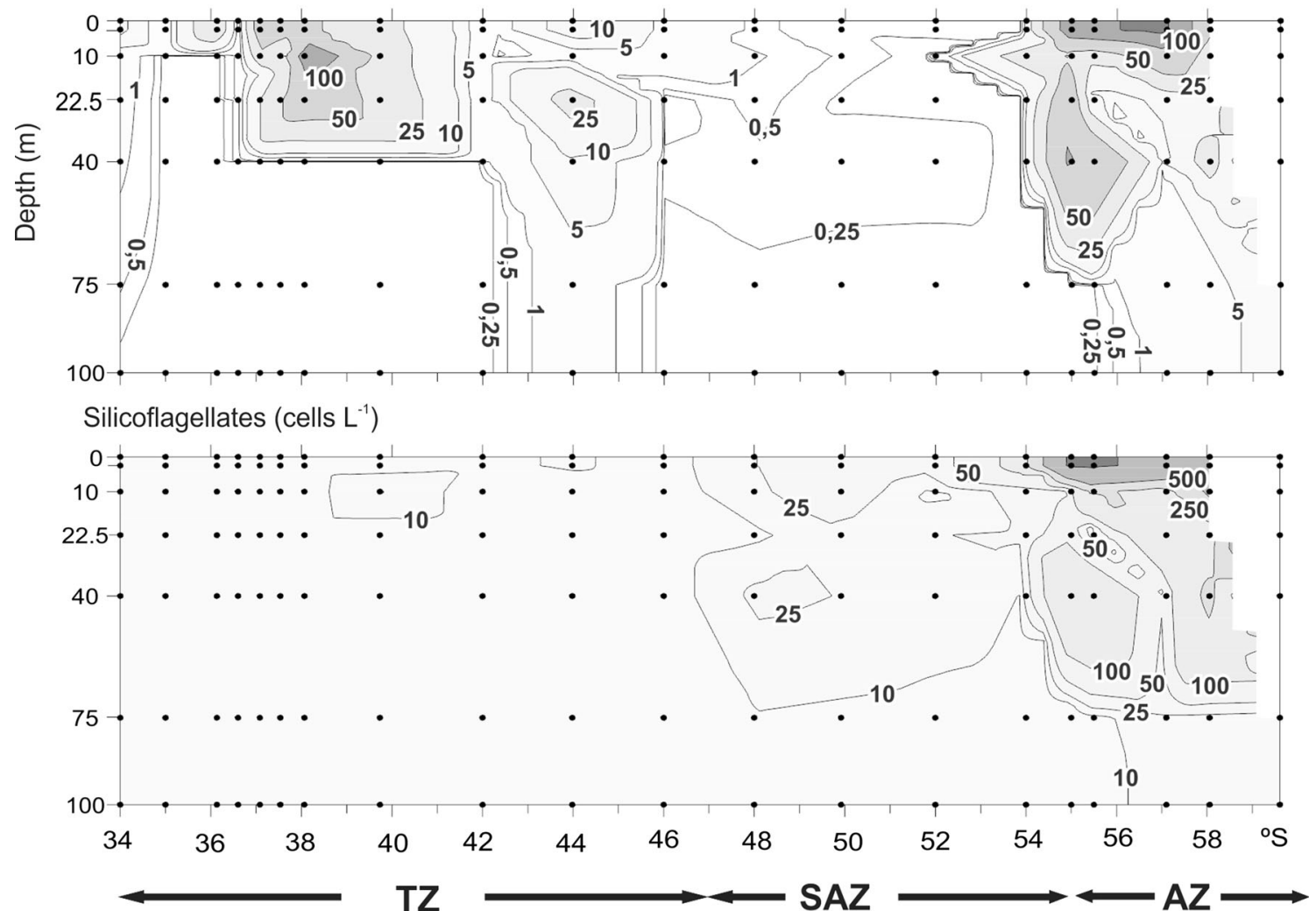

Fig. 3 Vertical profiles of chlorophyll $a$ concentrations and cell numbers in November 1994. TZ transitional zone, SAZ subantarctic zone, $A Z$ Antarctic zone

$25 \mathrm{~m}$ in 1995), but not in subantarctic waters $\left(49^{\circ}-55^{\circ} \mathrm{S}\right)$, despite the sharp increase in the concentration of macronutrients south of the SAF. This spatial pattern was similar to that reported previously (Podestá 1997; Marañón et al. 2000; Saraceno et al. 2005; Olguín et al. 2006).

Mean chlorophyll a concentration showed nonsignificant differences (ANOVA; $P>0.05$ ) between the springs of 1994, 1995 and 1993. However, the abundance of diatoms was significantly lower (ANOVA; $P<0.01$ ) in 1995 (mean 2,730 cell L ${ }^{-1}$ ) than in 1994 (mean 22,411 cell $\mathrm{L}^{-1}$ ) and 1993 (mean 17,651 cell $\mathrm{L}^{-1}$ ), suggesting that dinoflagellates and/or groups not considered in this study, such as nanoplanktonic organisms $(<10 \mu \mathrm{m})$, may play an important role in biomass contribution (Marañón et al. 2000; Barlow et al. 2002).

Biogeographic patterns of specific composition of silicoflagellates and diatoms

Among the four species of silicoflagellates identified, only Distephanus speculum was abundant, especially in southernmost waters, and widely distributed. Dictyocha messanensis and Distephanus pulchra were more frequent and abundant in the warm waters of the BMCZ, whereas 


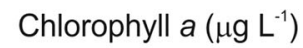

\section{Stations}

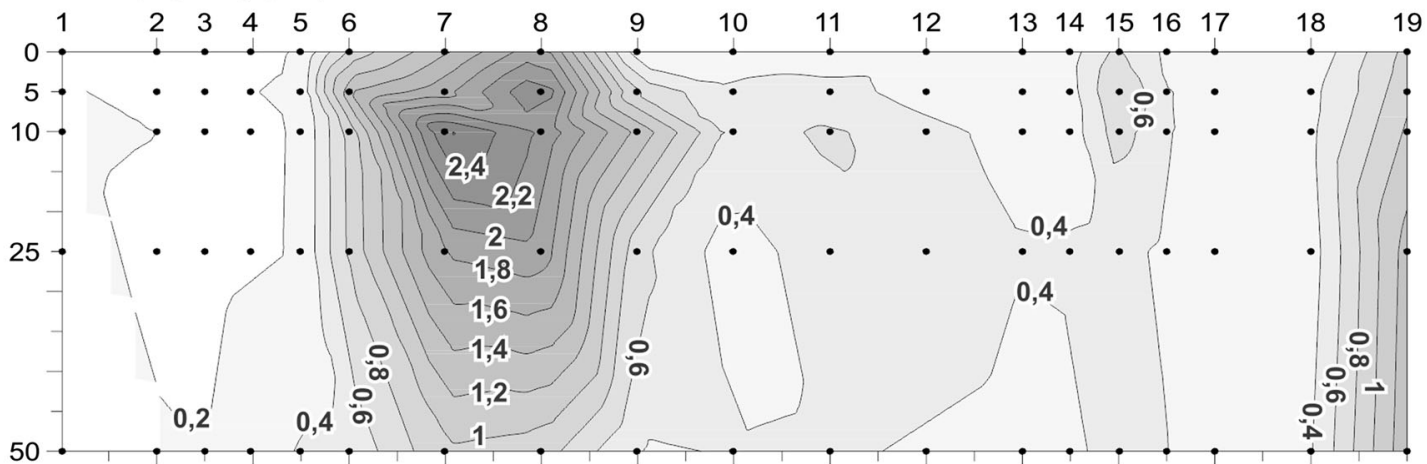

Diatoms (cells L ${ }^{-1} \times 1000$ )

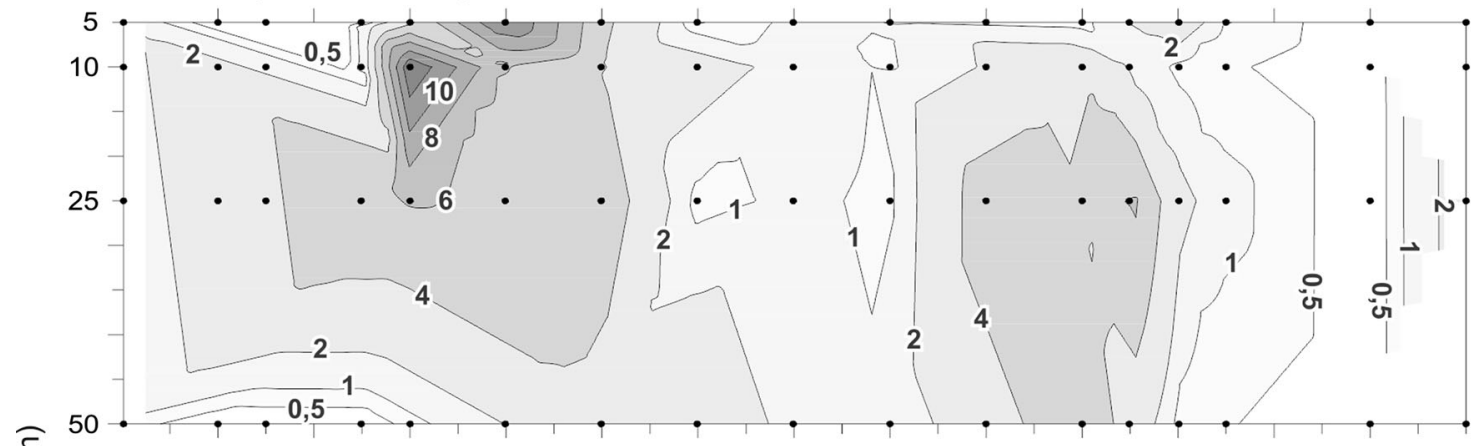

$\widehat{\xi}$
苂
ดे

Silicoflagellates (cells $\mathrm{L}^{-1}$ )

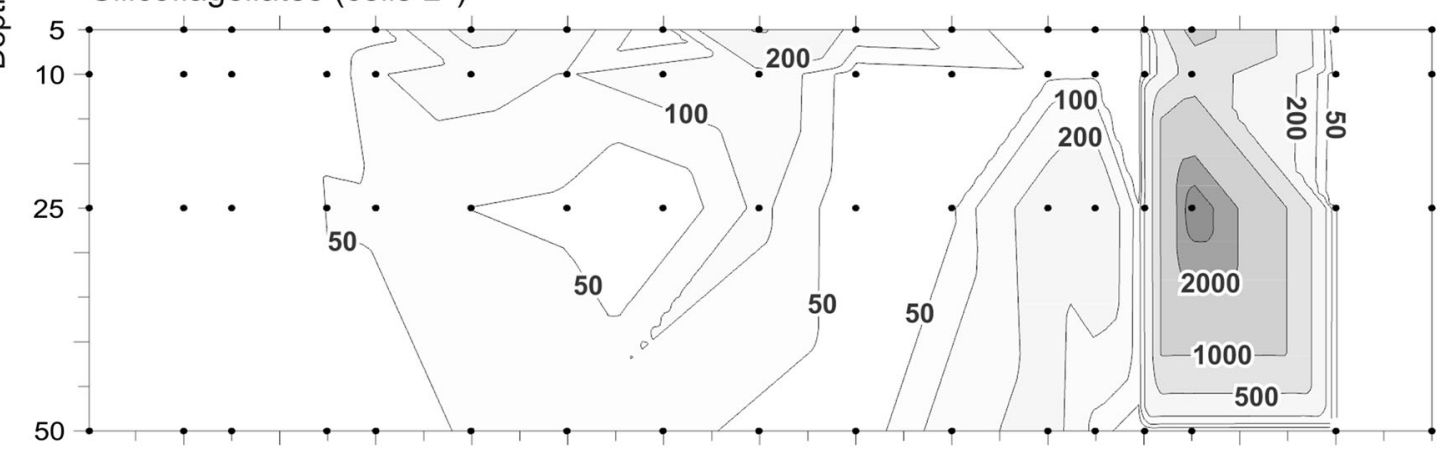

Dinoflagellates (cells $\mathrm{L}^{-1} \times 1000$ )

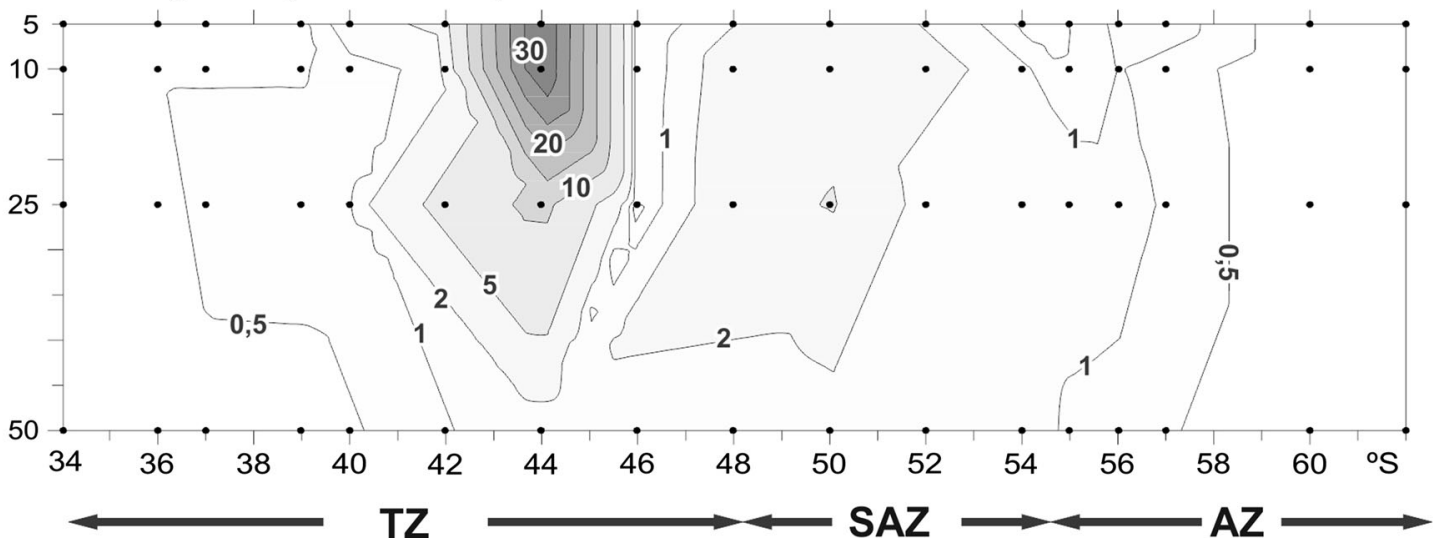

Fig. 4 Vertical profiles of chlorophyll $a$ concentrations and cell numbers in November 1995. TZ transitional zone, $S A Z$ subantarctic zone, $A Z$ Antarctic zone 
Dictyocha mandrai was present throughout the area surveyed (Figs. 5, 6). These distributional trends were similar in 1994 and 1995 and comparable to those recorded in 1993 (Olguín et al. 2006). This concordance suggests a consistent interannual pattern of the silicoflagellate distribution in the region. Moreover, a similar distribution pattern of the species according to their affinity with water temperature has been previously documented in the northwest (Takahashi and Blackwelder 1992) and southeast Atlantic Oceans (Eynaud et al. 1999).

In the three springs, 197 diatom species were identified for the whole region studied. Among them, 173 species (88\%) showed mean relative density lower than $1 \%$ and may thus be classified as rare (Rodríguez-Ramos et al. 2014), and 109 species (55\%) showed mean relative density lower than $0.1 \%$. The species richness of diatoms observed in this SWA region (mean: 146 species per survey) was higher than that reported (60 taxa) in a similar transect $\left(34^{\circ}-57^{\circ} \mathrm{S}\right)$ in the southeast Atlantic Ocean in February (Eynaud et al. 1999).

Cluster analyses (not shown) confirmed that the structure of the diatom assemblages was governed much more strongly by the latitudinal gradient than by depth, as shown in a previous study (Olguín et al. 2006). Therefore, the biogeographic analyses were focused on depth-integrated abundances.

The biogeographic zonation of transects based on species composition of diatoms was similar in the two years surveyed (Figs. 1, 2). The SAF defined the most important break, clearly separating a warm-water assemblage to the north and a cold-water one to the south. North of the SAF, the Transitional Zone (BMCZ) was subdivided into two subzones: Northern Transitional (NT) and Southern Transitional. South of the SAF, the Subantarctic and Antarctic Zones were identified, both with almost exclusively coldwater species of diatoms, most of which were common in subantarctic and antarctic waters (Figs. 5, 6).

The position of the boundaries between biogeographic zones varied little between years, except for the boundary between the Subantarctic and Antarctic Zones (environs of the PF), which was around $53-54^{\circ} \mathrm{S}$ in 1994 and ca. $56.5^{\circ} \mathrm{S}$ in 1995 (Figs. 1, 2).

Diatom species characteristic of the zones and their relative abundance in the samples are illustrated in Figs. 5 and 6. These species were selected in accordance with our previous set of criteria on frequency and abundance (Olguín et al. 2006). The species consistently present across most of the transect (widespread) were named "cosmopolitan" for the study region.

Most of the diatoms that characterized the transitional waters of the BMCZ, especially at the northernmost stations, were warm- and temperate-water species. This predominance reflects the strong influence of the Brazil
Current, which advects subtropical species into the BMCZ often as far south as the SAF (Figs. 5, 6). In 1994, warm- and temperate-water species, such as Chaetoceros contortus and Bacteriastrum hyalinum (followed by Bacteriastrum furcatum/delicatulum, Chaetoceros affinis, Pseudo-nitzschia multiseries, etc.) were particularly abundant in the Transitional Zone (Fig. 5). However, in 1995, several species usually considered characteristic of cold waters (Hasle and Syvertsen 1996), as Corethron criophilum and Fragilariopsis kerguelensis, but classified as "cosmopolitan" in this spring according to the aforementioned criterion, were frequent and abundant in the Transitional Zone. Moreover, species characteristic of this zone (e.g., B. hyalinum, Leptocylindrus danicus) (Olguín et al. 2006) were generally scarce in 1995 (Fig. 6).

The Subantarctic Zone (located between the SAF and the PF) was fairly well segregated in the cluster analyses (Figs. 1, 2). However, very few of the diatom species fitted the criteria of being characteristic for this zone in 1995 (e.g., Eucampia antarctica, Rhizosolenia simplex, Stephanopyxis turris, Fig. 6) and none of them in 1994 (Fig. 5). Species frequent in the subantarctic samples were usually also frequent in antarctic waters ("Subantarctic/Antarctic" in Figs. 5, 6).

Therefore, the zonation of the latitudinal transects showed characteristic species mainly in the extreme sectors: the Northern Transitional Subzone and the Antarctic Zone. Each contiguous sector (Southern Transitional Subzone and Subantarctic Zone) presented mainly common species with the respective extreme and only a few or no characteristic species. The species characteristic of the NT resulted exclusively from the comparison with the rest of the transect to the south, due to the lack in both surveys of stations in the Subtropical Zone (north of the BMCZ). The number of species characteristic of the NT would be probably fewer as result of a simultaneous comparison also with the Subtropical Zone, which showed greater species richness and numerous characteristic species at the site sampled in 1993 (Olguín et al. 2006).

"Cosmopolitan" species represented a rather small proportion of the overall species number (around 4-10\%), but the relative abundance of some of these species was very high, particularly in 1995 (e.g., Corethron criophilum, Fragilariopsis kerguelensis, Thalassionema nitzschioides, Fig. 6).

The PF is considered one of the most characteristic features of the Southern Ocean, often regarded as one of the sharpest and best defined biogeographic barriers in the world ocean (Deacon 1982; Sournia 1994; Eynaud et al. 1999; Boltovskoy et al. 2005). However, the number of species whose latitudinal distribution ranges were 
Fig. 5 Distribution of a selected group of diatom species and of the four silicoflagellates recorded in the area surveyed in November 1994. Stations and their latitude (in decimal degrees) ordered according to cluster results (Fig. 1).

"Cosmopolitan": widespread in the study region

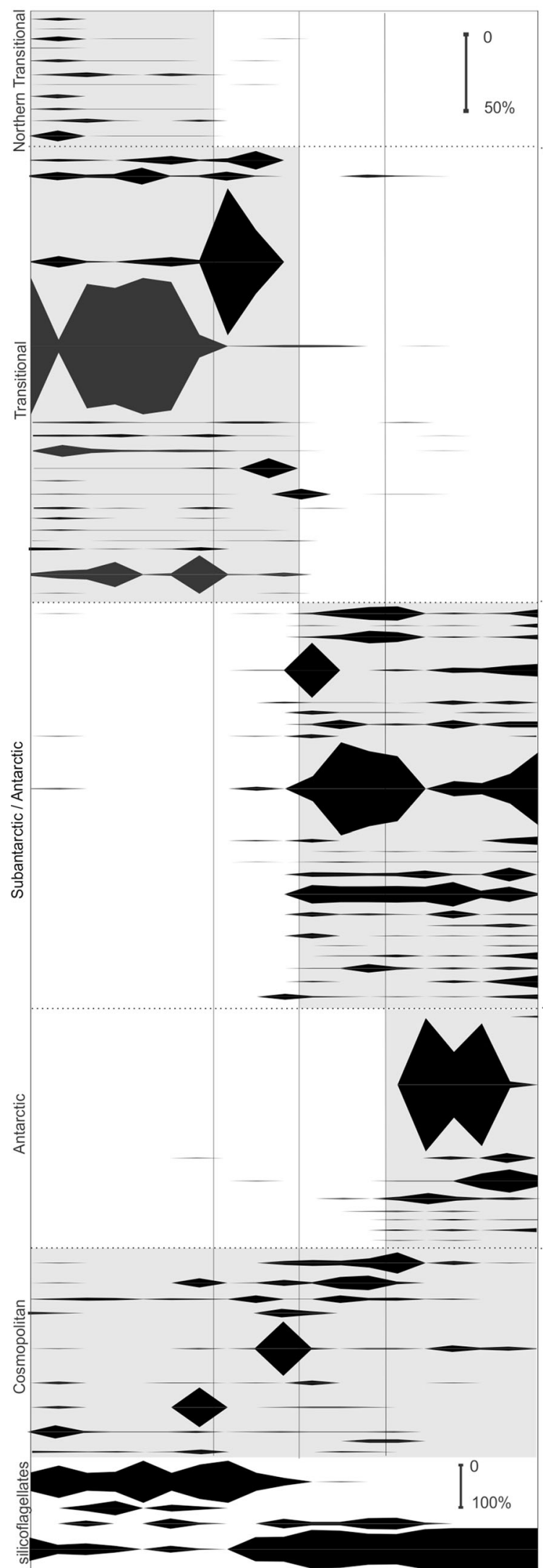

Alveus marinus

Asterolampra marylandica

Ahaetoceros diversus

Chaetoceros diversus

Chaetoceros lorenzianus

Chaetoceros messanensis

Coscinodiscus marginatus

Hemiaulus membranaceus

Pseudosolenia calcar-avis

Rhizosolenia clevei var. communis

Bacteriastrum furc / delic

Chaetoceros affinis

Bacteriastrum hyalinum

Chaetoceros contortus

Chaetoceros constrictus

Chaetocerus curvisetus

Chaetocerus didymus

Chaetoceros rostratus

Coscinodiscus radiatus

Ditylum brightwellii
Fragilariopsis doliolus

Hemiaulus hauckii

Leptocylindrus danicus

Eucampia cornuta

Pseudo-nitzchia multiseries

Roperia tesselata

Asteromphalus hookeri

Asteromphalus hyalinus

Chaetoceros atlanticus

Chaetoceros criophilus

Dactylosolen antarcticus

Eucampia antarctica

Fragilariopsis kerguelensis

Fragilariopsis rhombica Membraneis challenger Pleurosigma directum Pseudo-nitzchia lineola Rhizosolenia chunii Rhizosolenia antarctica Rhizosolenia simplex Thalassiosira gravida Thalassiosira lentiginosa Thalassiothrix anta Trichotoxon reinbolii Actinocy a cius actu Actinocyclus actinochilus

Chaetoceros debilis

Chaetoceros flexuosus Chaetoceros dichaeta Chaetoceros neglectus Rhizosolenia poly

Thessiosira polydactyla Thalassiosira gracilis

Actinocyclus curvatulus Azpeitia tabularis

Chaetoceros decipiens

Chaetoceros peruvianus

Corethron criophilum

Nitzschia bicapitata

Planktoniella sol

Proboscia alata

Thalassionema nitzchioides

Dictyocha messanensis

Distephanus pulchra

Dictyocha mandrai

Distephanus speculum

$\begin{array}{llllllllllllllllllll}2 & 3 & 4 & 6 & 7 & 8 & 10 & 9 & 11 & 12 & 13 & 14 & 15 & 16 & 17 & 18 & 20 & 21 & 22 & \text { stations }\end{array}$

$\begin{array}{lllllllllllllllllll}34 & 35 & 36.1 & 37.1 & 37.5 & 38.1 & 42 & 39.7 & 43.9 & 46 & 48 & 49.9 & 52 & 54 & 55 & 55.5 & 57.158 .1 & 59.1 \text { latitude } \$\end{array}$ 
Fig. 6 Distribution of a selected group of diatom species and of the four silicoflagellates recorded in the area surveyed in November 1995. Stations and their latitude (in decimal degrees) ordered according to cluster results (Fig. 2).

"Cosmopolitan": widespread in the study region

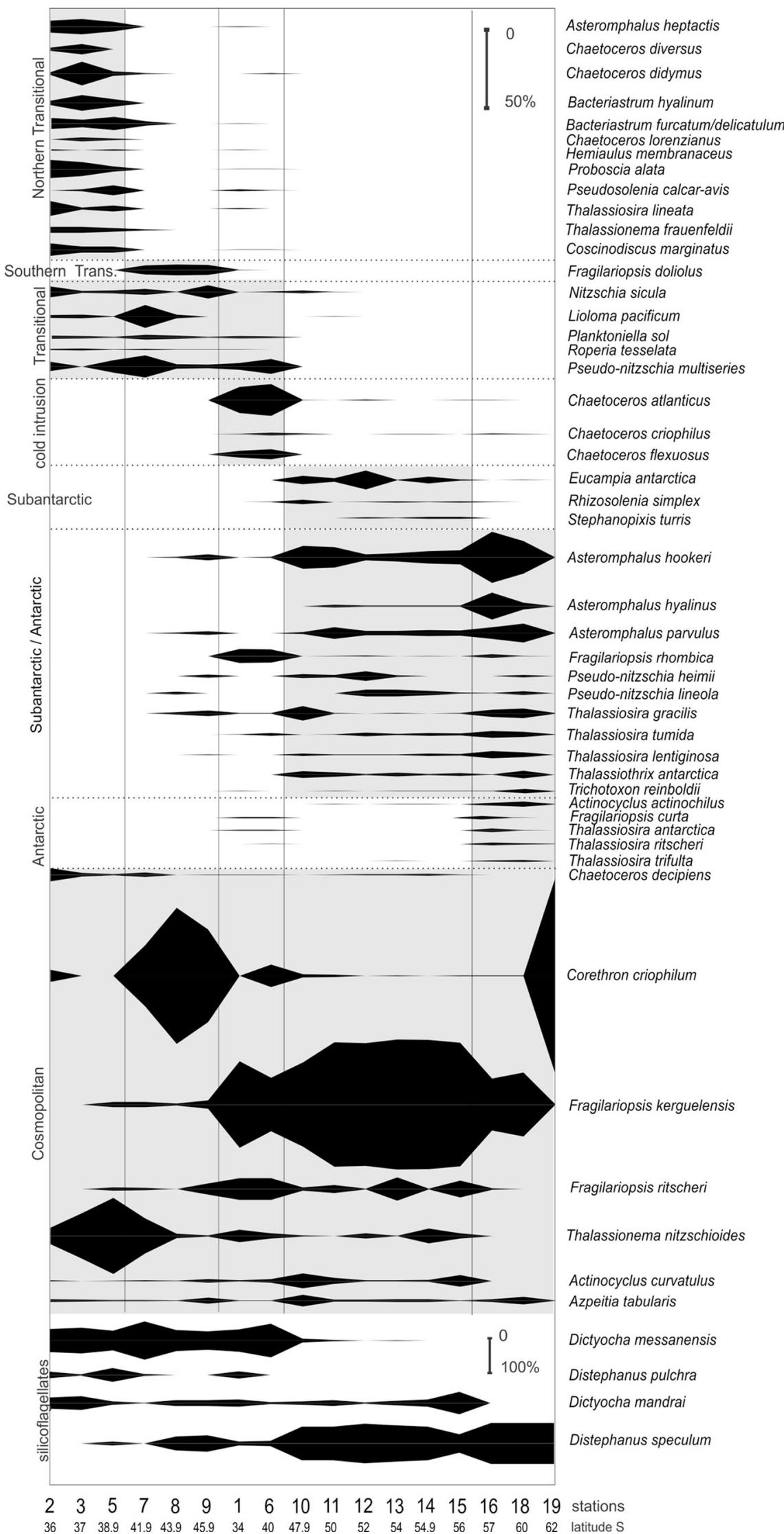


interrupted either by the PF or by the SAF (expressed as a percentage of the number of species present on either side of each front) showed that the PF was a weaker biogeographic boundary (30-40\% in 1993 to 1995 springs) than the SAF ( $\sim 80 \%$ in $1993 / 1994$ and $60 \%$ in 1995). The SAF showed a sharp decrease in temperature $\left(8-5{ }^{\circ} \mathrm{C}\right)$ and an increase in silicates $(>4 \mu \mathrm{M})$. This silicate concentration is considered a threshold for an optimum development of cold-water diatom species (Jacques 1989). Likewise, the
SAF is the northern limit of many cold-water diatom species in the southeast Atlantic Ocean (Froneman et al. 1995).

These results confirm the relevance of frontal features in the distribution of diatom species and other plankton groups in the SWA (Thompson et al. 1999; 2001; Boltovskoy et al. 2000; Thompson and Alder 2005) and in the southeast Atlantic Ocean (Froneman et al. 1995; Eynaud et al. 1999; Ward et al. 2003).

Table 1 General information on diatom assemblages recorded in the springs of 1993, 1994 and 1995

\begin{tabular}{|c|c|c|c|}
\hline & 1993 & 1994 & 1995 \\
\hline \multicolumn{4}{|l|}{ Total } \\
\hline Number of species recorded & 173 & 162 & 103 \\
\hline Mean number and range of species per station & $50(34-86)$ & $51(31-73)$ & $27(16-42)$ \\
\hline \multirow[t]{4}{*}{ Dominant species (mean relative abundance) } & F. kerguelensis $(20 \%)$ & C. contortus $(16 \%)$ & F. kerguelensis (35\%) \\
\hline & T. nitzschioides (8 \%) & F. kerguelensis (11\%) & C. criophilum (15\%) \\
\hline & F. doliolus $(6 \%)$ & C. debilis $(10 \%)$ & T. nitzschioides (7 \%) \\
\hline & C. rostratus $(5 \%)$ & B. hyalinum (6\%) & A. hookeri (5\%) \\
\hline \multirow[t]{5}{*}{ Common species (present in $>70 \%$ of the samples) } & A. tabularis & A. tabularis & A. tabularis \\
\hline & A. curvatulus & A. curvatulus & A. curvatulus \\
\hline & C. criophilum & C. criophilum & A. parvulus \\
\hline & T. nitzschioides & C. decipiens & F. kerguelensis \\
\hline & F. kerguelensis & F. kerguelensis & T. nitzschioides \\
\hline \multicolumn{4}{|l|}{$\mathrm{TZ}$} \\
\hline Mean number and range of species per station & $53(34-87)$ & $57(27-73)$ & $28(18-42)$ \\
\hline Proportion of cold-water species & $16 \%$ & $13 \%$ & $25 \%$ \\
\hline Relative cell abundance of cold-water species & $8 \%$ & $0.9 \%$ & $20 \%$ \\
\hline Relative cell abundance of warm-water species & $44 \%$ & $89 \%$ & $31 \%$ \\
\hline \multirow[t]{4}{*}{ Dominant species (mean relative abundance) } & F. doliolus $(12 \%)$ & C. contortus $(38 \%)$ & C. criophilum (21\%) \\
\hline & T. nitzschioides (12\%) & B. hyalinum (13\%) & T. nitzschioides (13\%) \\
\hline & C. rostratus $(10 \%)$ & P. multiseries (5\%) & F. kerguelensis $(10 \%)$ \\
\hline & F. kerguelensis (5 \%) & & \\
\hline \multicolumn{4}{|l|}{ SAZ } \\
\hline Mean number and range of species per station & $41(37-50)$ & $36(31-42)$ & $26(22-31)$ \\
\hline Proportion of cold-water species & $51 \%$ & $49 \%$ & $62 \%$ \\
\hline Relative cell abundance of cold-water species & $68 \%$ & $68 \%$ & $89 \%$ \\
\hline Relative cell abundance of warm-water species & $1.2 \%$ & $4.8 \%$ & $0.42 \%$ \\
\hline \multirow[t]{3}{*}{ Dominant species (mean relative abundance) } & F. kerguelensis (42\%) & F. kerguelensis $(37 \%)$ & F. kerguelensis $(60 \%)$ \\
\hline & C. convolutus (8\%) & C. atlanticus (11\%) & A. hookeri $(7 \%)$ \\
\hline & E. antarctica $(7 \%)$ & P. lineola $(10 \%)$ & F. ritscheri $(5 \%)$ \\
\hline \multicolumn{4}{|l|}{ AZ } \\
\hline Mean number and range of species per station & $48(40-56)$ & $50(38-63)$ & $25(16-32)$ \\
\hline Proportion of cold-water species & $67 \%$ & $62 \%$ & $87 \%$ \\
\hline Relative cell abundance of cold-water species & $81 \%$ & $58 \%$ & $97 \%$ \\
\hline Relative cell abundance of warm-water species & $0.06 \%$ & $1.2 \%$ & $0 \%$ \\
\hline \multirow[t]{4}{*}{ Dominant species (mean relative abundance) } & F. kerguelensis (37 \%) & C. debilis (32\%) & F. kerguelensis (29\%) \\
\hline & C. criophilum (5\%) & F. kerguelensis (19\%) & A. hookeri $(22 \%)$ \\
\hline & P. lineola $(5 \%)$ & P. lineola $(8 \%)$ & A. hyalinus $(9 \%)$ \\
\hline & P. heimii $(5 \%)$ & & \\
\hline
\end{tabular}

The biogeographic areas defined are Transitional Zone (TZ), Subantarctic Zone (SAZ) and Antarctic Zone (AZ). Species names in Figs. 5 and 6 


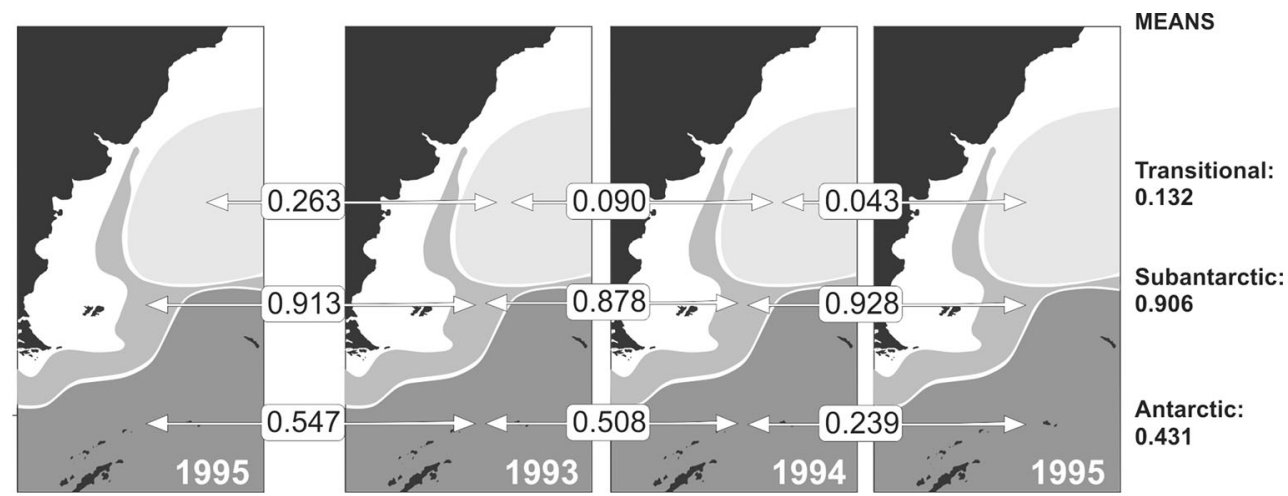

Fig. 7 Similarity values (Pearson correlation index) of relative species abundance in diatom assemblages for the Transitional, Subantarctic and Antarctic Zones (mean of samples from each zone)

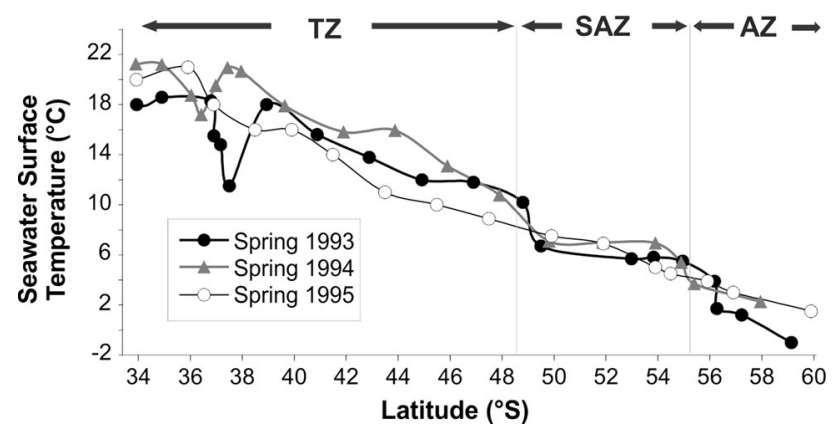

Fig. 8 Latitudinal profiles of seawater surface temperature, modified from Thompson (2004). TZ Transitional Zone, SAZ Subantarctic Zone, $A Z$ Antarctic Zone

One interesting biogeographic feature of the area surveyed was the presence of isolated patches of water with diatom assemblages sharply different from those of the nearby stations. In 1995, stations 1 (at the northernmost end of the transect) and 6 hosted around $60 \%$ of coldwater diatoms, whereas stations located nearby, both to the south and to the north, presented cold-water diatoms below $10 \%$ (Fig. 2). We argue that these anomalies are due to lateral intrusions of Malvinas Current waters, which shed eddies or meanders that wander into the BMCZ and eventually dissipate there (Matano et al. 2010). Such cold intrusions were also observed in the region in the spring of 1993 (Olguín et al. 2006). In 1993, an assemblage dominated by the warm-water diatom Fragilariosis doliolus was observed in the southern end $\left(41^{\circ} \mathrm{S}\right)$ of the BMCZ (Olguín et al. 2006). This association likely indicates the presence of isolate cells of pure subtropical input shed from the Brazil Current. The same species dominated a warm core eddy shed from the Agulhas Return Current observed in the southeast Atlantic Ocean in the Subtropical Convergence (Froneman et al. 1997). between the three years. High values indicate little interannual variation, and vice versa. Analysis based on 65 selected diatom species (each $>5 \%$ of the overall assemblage in at least one sample)

Interannual changes in diatom assemblage composition

The biogeographic divisions observed in the springs of 1994 and 1995 were very similar and also closely comparable to those recorded in the spring of 1993 (Olguín et al. 2006). This zonation, based on diatom assemblages, was also almost identical to those based on other plankton organisms, such as foraminifers (Boltovskoy et al. 1996, 2000) and tintinnids recorded in the same samples (Thompson et al. 1999; Thompson and Alder 2005).

Conversely, differences in species richness and dominant species were evident between the springs of 1994 and 1995 (Table 1). In 1994, 162 species were identified, ranging between 6 and 59 per sample and between 31 and 73 per station, whereas in 1995, 103 species were identified, ranging between 8 and 42 per sample and between 16 and 42 per station.

Specific composition of diatoms in each biogeographic area, especially in the Transitional Zone, differed markedly between years. Year-to-year variations are partly due to random differences in the records of the scarce species. However, even when this bias was taken into account (e.g., comparisons based only on the most abundant species), strong interannual differences were evident.

The similarity of relative species abundance in diatom assemblages between the three years was analyzed for each of the three main biogeographic zones (Fig. 7). These interannual similarities were lowest for the Transitional Zone (where all correlation coefficients approached zero), intermediate for the Antarctic Zone and highest for the Subantarctic Zone. These differences in the interannual variability of diatom assemblage structure may be associated with the different degrees of spatiotemporal heterogeneity in the hydrographic features of the three main biogeographic zones. In the Transitional Zone, the 


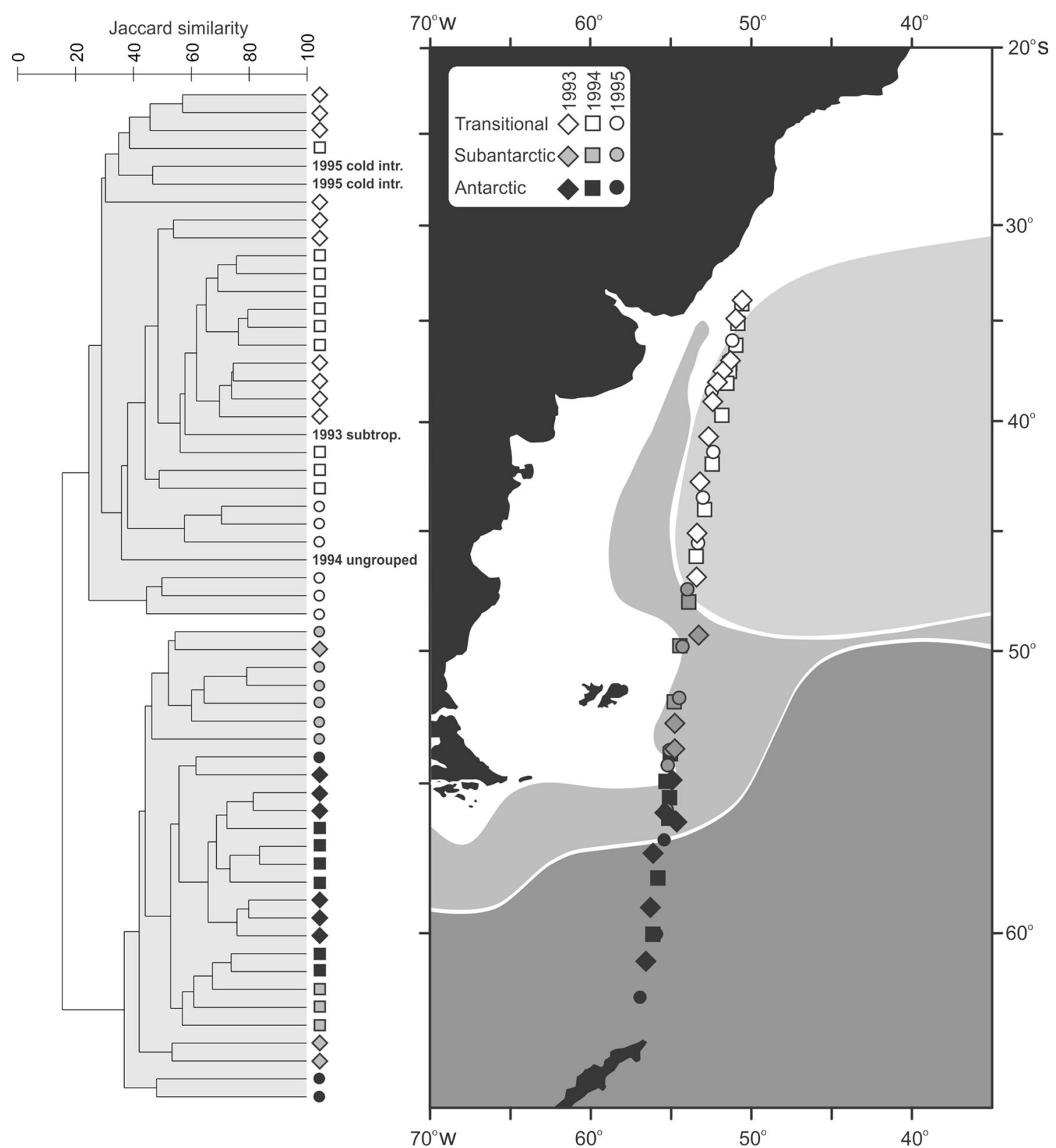

Fig. 9 Grouping (UPGMA) of the stations of the three surveys based on diatom data (Jaccard's index). Species used (117) are restricted to those present at levels above $1 \%$ in at least one sample of each

intervening of warm and cold waters causes multiple density layers with strong vertical and horizontal gradients in the euphotic zone (Brandini et al. 2000). Therefore, the most complex physical structure of this zone (Willson and Rees 2000; d'Ovidio et al. 2010) likely provides habitat for various species. In contrast, the persistent oligotrophic (although nitrate-rich waters) regime of the northern sector of the Subantarctic Zone has been associated with scarce diatom abundance, lack of an important spring/summer bloom (Longhurst 1998; Saraceno et al. 2005) and dominance of nanosized cells (Longhurst 1998). transect. Biogeographic assignments are those indicated in Olguín et al. (2006) and Figs. 1 and 2

The interannual variation in the regional circulation system (Witter and Gordon 1999) introduced large-scale changes. These differences were particularly evident in the relative contribution of some warm- and cold-water dominant species (Table 1). The spring of 1995 was characterized by the lowest species richness and by the highest dominance of cold-water diatoms in both species number and abundance. Chaetoceros contortus, a typically subtropical/temperate species, was largely dominant (38\%) in the Transitional Zone in 1994, whereas it was recorded in only one of the six samples from this zone 
(mean $0.07 \%$ ) in 1995. In 1993, Fragilariopsis doliolus, a subtropical species, was abundant in the Transitional Zone, whereas in 1995 its contribution decreased. In contrast, Corethron criophilum, a cosmopolitan species but abundant in antarctic waters (Hasle and Syvertsen 1996), was much more abundant in 1995 than in the other two years surveyed (Table 1). Other cold-water diatoms, as Fragilariopsis kerguelensis, F. ritscheri, Asteromphalus hookeri, A. parvulus and Thalassiosira gracilis (Figs. 5, 6), were more abundant in the Transitional Zone in 1995 than in 1993/1994. The warm/temperate species Chaetoceros curvisetus, Chaetoceros rostratus and Pseudosolenia calcar-avis showed the opposite trend (Figs. 5, 6). Another remarkable difference was that some typically subtropical forms, such as Chaetoceros contortus, Fragilariopsis doliolus, Hemiaulus hauckii and Planktoniella sol, were recorded at several stations south of the SAF in 1994 (Fig. 5).

These variations in the structure of diatom assemblages most probably reflect the large-scale anomalies for the SWA described between 1993 and 1997, involving: (1) a southward extension of the Brazil Current in 1994 (as compared with 1995) (Boebel et al. 1999); (2) a weakening of the Malvinas Current between 1993 and early 1995, followed by a strengthening until early 1997 (Witter and Gordon 1999); and (3) the occurrence of a weak 'El Niño' in 1994-1995, followed by a weak 'La Niña' in 1995-1996, along the South American and South African coasts and the Antarctic Peninsula (Gammelsrød et al. 1998; Severov et al. 2004; Vernet et al. 2008), including the presence of a $>100-\mathrm{km}$-wide band of cold subantarctic water limited to November 1995 (Thompson and Alder 2005). In accordance with these anomalies, the surface temperature in most of the BMCZ was $1-5^{\circ} \mathrm{C}$ (mean $=2.3{ }^{\circ} \mathrm{C}$ ) higher in the spring of 1994 than in the spring of 1995, whereas surface temperatures southwards from $49^{\circ} \mathrm{S}$ were very similar in both periods (Fig. 8).

These events favored a greater southward penetration of subtropical waters in the Transitional Zone in 1994, which led to an enhanced presence of subtropical species and a greater influence of subantarctic/antarctic waters in 1995 and thus to a higher dominance of cold-water diatoms (Table 1). Interestingly, the mentioned interannual changes observed in diatom assemblages agree with those described for the tintinnids recorded in the same samples (Thompson 2004; Thompson and Alder 2005).

Despite the relevant interannual differences in diatomspecific composition throughout the area surveyed, especially in its northern sector (Fig. 7), the coupling between diatom composition and hydrographic setting was consistent enough for some boundaries to persist through time. This consistency was clearly evident in the analyses of pooled data (presence of 117 species in the three surveys,
Fig. 9). The samples from the Transitional Zone formed a homogeneous group, sharply separated from all other sites, and the boundary between the Transitional and the Subantarctic Zones was also coincident during the three springs analyzed. Conversely, the assemblages from the Subantarctic and Antarctic Zones were much less clearly defined, both geographically and in species composition.

In summary, the biogeographic zones and their boundaries based on diatom assemblages were consistent in the three consecutive springs, as well as in concordance with results on other microplankton organisms, thus emerging as a persistent regional feature. The Polar Front, often regarded as one of the sharpest and best defined biogeographic barriers in the world ocean, was a weaker biogeographic boundary for diatom species than the Subantarctic Front in the studied region. Unlike the Northern Transitional Subzone and the Antarctic Zone, the Southern Transitional Subzone and the Subantarctic Zone showed only a few or no characteristic species. Interannual changes in diatom assemblage structure, especially in the Transitional Zone, agreed with reported differences in large-scale hydrographic conditions: The increased effect of the Brazil Current in the spring of 1994 enhanced the proportion and dispersion of subtropical species, whereas the increased effect of the Malvinas Current in the spring of 1995 enhanced the proportion and dispersion of cold-water species and decreased their diversity.

Acknowledgments We thank the crew and officers of the supply and research vessel "Ary Rongel" of the Brazilian Navy for logistical and technical assistance. This work was supported by grants from the University of Buenos Aires, Argentina; the Argentine Antarctic Institute and the Conselho Nacional de Desenvolvimiento Cientifico e Tecnologico, Brazil.

\section{References}

Almandoz GO, Ferrario ME, Ferreyra GA, Schloss IR, Esteves JL, Paparazzo FE (2007) The genus Pseudo-nitzschia (Bacillariophyceae) in continental shelf waters of Argentina (Southwestern Atlantic Ocean, 38-55 S). Harmful Algae 6:93-103

Armbrust EV (2009) The life of diatoms in the world's oceans. Nature 459:185-192

Barlow RG, Aiken J, Holligan PM, Cummings DG, Maritorena S, Hooker SB (2002) Phytoplankton pigment and absorption characteristics along meridional transects in the Atlantic Ocean. Deep Sea Res I 49:637-660

Boebel O, Schmid C, Podestá G, Zenk W (1999) Intermediate water in the Brazil-Malvinas Confluence Zone: a Langrangian view. J Geophys Res 104:21063-21082

Boltovskoy D (ed) (1999) South Atlantic Zooplankton. Backhuys, Leiden

Boltovskoy D (2005) Diversity and endemism in cold waters of the South Atlantic: contrasting patterns in the plankton and the benthos. Sci Mar 69:17-26

Boltovskoy E, Boltovskoy D, Correa N, Brandini F (1996) Planktonic foraminifera from the Southwestern Atlantic (30 to $\left.60^{\circ} \mathrm{S}\right)$ : 
species-specific patterns in the upper $50 \mathrm{~m}$. Mar Micropaleontol 28:53-72

Boltovskoy E, Boltovskoy D, Brandini F (2000) Planktonic foraminifera from south-western Atlantic epipelagic waters: abundance, distribution and year-to-year variations. J Mar Biol Assoc UK 78:203-213

Bopp L, Aumont O, Cadule P, Alvain S, Gehlen M (2005) Response of diatoms distribution to global warming and potential implications: a global model study. Geophys Res Lett. doi:10.1029/ 2005GL023653

Boyd PW, Strzepek R, Fu F, Hutchins DA (2010) Environmental control of open-ocean phytoplankton groups: now and in the future. Limnol Oceanogr 55:1353-1376

Brandini FP, Boltovskoy D, Piola A, Kocmur S, Röttgers R, Abreu PC, Mendes Lopes R (2000) Multiannual trends in fronts and distribution of nutrients and chlorophyll in the southwestern Atlantic (30-62 ${ }^{\circ}$ ). Deep Sea Res I 47:1015-1033

Campos E, Busalacchi A, Garzoli S, Lutjeharms J, Matano R, Nobre P, Olson D, Piola A, Tanajura C, Wainer I (1999) The South Atlantic and the climate. In: Proceedings of the OCEANOBS'99 the ocean observing system for climate, 18-22 Oct 1999, St. Raphael, France

Cermeño P, Falkowski PG (2009) Controls on diatom biogeography in the ocean. Science 325:1539-1541

Cermeño P, Dutkiewicz S, Harris RP, Follows M, Schofield O, Falkowski PG (2008) The role of nutricline depth in regulating the ocean carbon cycle. PNAS 105:20344-20349

Cermeño P, de Vargas C, Abrantes F, Falkowski PG (2010) Phytoplankton biogeography and community stability in the ocean. PLoS One 5:e10037. doi:10.1371/journal.pone.0010037

Cermeño P, Teixeira IG, Branco M, Figueiras FG, Marañón E (2014) Sampling the limits of species richness in marine phytoplankton communities. J Plankton Res 36:1135-1139

Chust G, Irigoien X, Chave J, Harris RP (2013) Latitudinal phytoplankton distribution and the neutral theory of biodiversity. Glob Ecol Biogeogr 22:531-543

Combes V, Matano RP (2014a) A two-way nested simulation of the oceanic circulation in the Southwestern Atlantic. J Geophys Res Oceans 119:731-756

Combes V, Matano R (2014b) Trends in the Brazil/Malvinas Confluence region. Geophys Res Lett. doi:10.1002/ 2014GL062523

d'Ovidio F, De Montec S, Alvainf S, Dandonneau Y, Lévy M (2010) Fluid dynamical niches of phytoplankton types. Proc Natl Acad Sci USA 107:18366-18370

Deacon GER (1982) Physical and biological zonation in the Southern ocean. Deep Sea Res 29:1-15

Eynaud F, Giraudeau J, Pichon JJ, Pudsey CJ (1999) Sea-surface distribution of coccolithophores, diatoms, silicoflagellates and dinoflagellates in the South Atlantic Ocean during the late austral summer 1995. Deep Sea Res I 46:451-482

Fernandes LF, Brandini FP (1999) Microplankton communities in the Southwestern Atlantic Ocean: biomass and distribution in November 1992. Rev Bras Oceanogr 47:189-205

Follows M, Dutkiewicz S, Grant S, Chisholm SW (2007) Emergent biogeography of microbial communities in a model ocean. Science 315:1843-1846

Froneman PW, Perissinotto R, McQuaid CD, Laubscher RK (1995) Summer distribution of netphytoplankton in the Atlantic sector of the Southern Ocean. Polar Biol 15:77-84

Froneman PW, Perissinotto R, Pakhomov EA (1997) Biogeographical structure of the microphytoplankton assemblages in the region of the Subtropical Convergence and across a warm-core eddy during austral winter. J Plankton Res 19:519-531

Gammelsrød T, Bartholomae C, Boyer D, Filipe V, O'Toole M (1998) Intrusion of warm surface layers along the Angolan-
Namibian coast in February-March 1995: the 1995 Benguela Niño. S Afr J Mar Sci 19:41-56

Gayoso AM, Podestá GP (1996) Hydrography and phytoplankton of the Brazil-Malvinas currents confluence. J Plankton Res 18:941-951

Gibb SW, Barlow RG, Cummings DG, Rees NW, Trees CC, Holligan P, Suggett D (2000) Surface phytoplankton pigment distributions in the Atlantic Ocean: an assessment of basin scale variability between $50^{\circ} \mathrm{N}$ and $50^{\circ} \mathrm{S}$. Prog Oceanogr 45:339-368

Gonçalves-Araujo R, Silva de Souza M, Borges Mendes CR, Tavano VM, Pollery RC, Eiras Garcia CA (2012) Brazil Malvinas confluence: effects of environmental variability on phytoplankton community structure. J Plankton Res 34:399-415

Goni GJ, Wainer I (2001) Investigation of the Brazil current front variability from altimeter data. J Geophys Res 106:3111731128. doi:10.1029/2000JC000396

Hasle GR (1976) The biogeography of some marine planktonic diatoms. Deep-Sea Res 23:319-338

Hasle GR, Syvertsen EE (1996) Marine diatoms. In: Tomas CR (ed) Identifying marine phytoplankton. Academic Press, San Diego, pp 5-385

Imawaki S, Bower AS, Beal L, Qiu B (2013) Western boundary currents. In: Siedler G, Griffies SM, Gould WJ, Church J (eds) Ocean circulation and climate-a 21st century perspective, 2nd edn. Academic Press, London, pp 305-338

Jacques G (1989) Primary production in the open Antarctic Ocean during the austral summer. a review. Vie Milieu 39:1-17

Lange KB (1985) Spatial and seasonal-variations of diatom assemblages off the Argentinean coast (South Western Atlantic). Oceanol Acta 8:361-369

Lange CB, Mostajo EL (1985) Phytoplankton diatoms and silicoflagellates from the Southwestern Atlantic Ocean. Bot Mar 28:469-476

Longhurst A (1998) Ecological geography of the sea. Academic Press, San Diego

Marañón E, Holligan PM, Varela M, Mouriño B, Bale AJ (2000) Basin-scale variability of phytoplankton biomass, production and growth in the Atlantic Ocean. Deep Sea Res Part I 47:825-857

Matano RP, Palma ED, Piola AR (2010) The influence of the Brazil and Malvinas currents on the Southwestern Atlantic Shelf circulation. Ocean Sci 6:983-995

Olguín HF, Alder VA (2011) Species composition and biogeography of diatoms in antarctic and subantarctic (Argentine shelf) waters (37-76 ${ }^{\circ}$ S). Deep Sea Res II 58:139-152

Olguín HF, Boltovskoy D, Lange C, Brandini F (2006) Distribution of spring microphytoplankton (mainly diatoms) in the upper $50 \mathrm{~m}$ of the Southwestern Atlantic Ocean $\left(30^{\circ}\right.$ to $\left.61^{\circ} \mathrm{S}\right)$. J Plankton Res 28:1107-1128

Olson DB, Podestá GP, Evans RH, Brown OB (1988) Temporal variations in the separation of Brazil and Malvinas currents. Deep Sea Res 35:1971-1990

Orsi AH, Whitworth T III, Nowlin WD Jr (1995) On the meridional extent and fronts of the antarctic circumpolar current. Deep Sea Res Part I 42:641-673

Peterson RG (1992) The boundary currents in the western Argentine Basin. Deep Sea Res 39:623-644

Peterson RG, Stramma L (1991) Upper-level circulation in the South Atlantic Ocean. Prog Oceanogr 26:1-73

Podestá GP (1997) Utilización de datos satelitarios en investigaciones oceanográficas y pesqueras en el Océano Atlántico Sudoccidental. In: Boschi E (ed) El Mar Argentino y sus Recursos Pesqueros. INIDEP 1, Mar del Plata, Argentina, pp 195-222

Ragueneau O, Treguer P, Leynaert A, Anderson RF, Brzezinski MA, DeMaster DJ, Dugdale RC, Dymond J, Fischer G, Francois R, Heinze C, Maier-Reimer E, Martin-Jezequel V, Nelson DM, 
Quéguiner B (2000) A review of the Si cycle in the modern ocean: recent progress and missing gaps in the application of biogenic opal as a paleoproductivity proxy. Global Planet Change 26:317-365

Rivas AL, Dogliotti AI, Gagliardini DA (2006) Seasonal variability in satellite-measured surface chlorophyll in the Patagonian Shelf. Cont Shelf Res 26:703-720

Rodríguez-Ramos T, Dornelas M, Marañón E, Cermeño P (2014) Conventional sampling methods severely underestimate phytoplankton species richness. J Plankton Res 36:334-343

Romero O, Armand LK (2010) Marine diatoms as indicators of modern changes in oceanographic conditions. In: Smol JP, Stoermer EF (eds) The diatoms: applications for the environmental and earth sciences. Cambridge University Press, Cambridge, pp 373-400

Romero SI, Piola AR, Charo M, Eiras Garcia CA (2006) Chlorophyll $a$ variability off Patagonia based on SeaWiFS data. J Geophys Res 111:C05021. doi:10.1029/2005JC003244

Sabatini ME, Akselman R, Reta R, Negri RM, Lutz VA, Silva RI, Segura V, Gil MN, Santinelli NH, Sastre AV, Daponte MC, Antacli JC (2012) Spring plankton communities in the southern Patagonian shelf: hydrography, mesozooplankton patterns and trophic relationships. J Mar Syst 94:33-51

Sar EA, Sunesen I, Castaños C (2001) Marine diatoms from Buenos Aires coastal waters (República Argentina). I. Thalassiosiraceae. Nova Hedwigia 73:199-228

Sar EA, Sunesen I, Lavigne AS (2002) The diatom genus Thalassiosira: species from the northern San Matías Gulf (Río Negro, Argentina). Nova Hedwigia 74:373-386

Saraceno M, Provost C, Piola A (2005) On the relationship between satellite retrieved surface temperature fronts and chlorophyll-a in the Western South Atlantic. J Geophys Res 110:C11016. doi:10. 1029/2004JC002736

Schloss I, Ferreyra G, Ferrario ME, Almandoz G, Codina R, Bianchi A, Balestrini C, Ochoa H, Ruiz Pino D, Poisson A (2007) Role of plankton communities in sea-air variations in $\mathrm{pCO}_{2}$ in the $\mathrm{SW}$ Atlantic Ocean. Mar Ecol Prog Ser 332:93-106

Severov D, Mordecki E, Pshennikov V (2004) SST anomaly variability in southwestern Atlantic and El Niño/Southern oscillation. Adv Space Res 33:343-347

Simonsen R (1974) The diatom plankton of the Indian Ocean expedition of RV Meteor 1964-1965. Meteor Forsch-Ergebnisse D 19:1-66

Smetacek VS (1985) Role of sinking in the diatom life-history cycles: ecological, evolutionary and geological significance. Mar Biol $84: 239-251$
Sournia A (1994) Pelagic biogeography and fronts. Prog Oceanog 34:109-120

Stoermer EF, Smol JP (2001) The diatoms: applications for the environmental and earth sciences. Cambridge University Press, Cambridge

Sullivan CW, Arrigo KR, McClain CR, Comiso JC, Firestone J (1993) Distributions of phytoplankton blooms in the Southern Ocean. Science 262:1832-1837

Takahashi K, Blackwelder PL (1992) The spatial distribution of Silicoflagellates in the region of the Gulf Stream warm-core ring 82B: application to water mass tracer studies. Deep Sea Res 39:327-346

Thompson GA (2004) Tintinnid diversity trends in the Southwestern Atlantic Ocean $\left(29\right.$ to $\left.60^{\circ} \mathrm{S}\right)$. Aquat Microb Ecol 35:93-103

Thompson GA, Alder VA (2005) Patterns in tintinnid species composition and abundance in relation to hydrological conditions of the Southwestern Atlantic during austral spring. Aquat Microb Ecol 40:85-101

Thompson GA, Alder VA, Boltovskoy D, Brandini F (1999) Abundance and biogeography of tintinnids (Ciliophora) and associated microzooplankton in the Southwestern Atlantic Ocean. J Plankton Res 21:1265-1298

Thompson GA, Alder VA, Boltovskoy D (2001) Tintinnids (Ciliophora) and other microzooplankton $(>30 \mu \mathrm{m})$ in Southwestern Atlantic shelf break waters. Mar Ecol 22:343-355

Vernet M, Martinson D, Iannuzzi R, Stammerjohn S, Kozlowski W, Sines K, Smith R, Garibotti I (2008) Primary production within the sea-ice zone west of the Antarctic Peninsula: I-sea ice, summer mixed layer, and irradiance. Deep Sea Res II 55:2068-2085

Ward P, Whitehouse M, Brandon M, Shreeve R, Woodd-Walken R (2003) Mesozooplankton community structure across the antarctic circumpolar current to the north of South Georgia: Southern Ocean. Mar Biol 143:121-130

Werner D (1977) The biology of diatoms. Botanical monographs 13. University of California Press, California

Willson HR, Rees NW (2000) Classification of mesoscale features in the Brazil-Falkland current confluence zone. Prog Oceanogr 45:415-426

Witter D, Gordon L (1999) Interannual variability of South Atlantic circulation from 4 years of TOPEX/POSEIDON satellite altimeter observations. J Geophys Res 104:20927-20948 